\title{
Glycogen storage in the Riftia pachyptila trophosome: contribution of host and symbionts
}

\author{
Angelika Sorgo ${ }^{1}$, Francoise Gaill ${ }^{2}$, Jean-Pierre Lechaire ${ }^{2}$, \\ Cordelia Arndt ${ }^{2,3}$, Monika Bright ${ }^{1, *}$ \\ ${ }^{1}$ Department of Marine Biology, Institute of Ecology and Conservation Biology, University of Vienna, Althanstrasse 14, \\ 1090 Vienna, Austria \\ ${ }^{2}$ Biologie Cellulaire et Moleculaire du Developpement, Biologie Marine UMR 7622 CNRS, Université P. et M. Curie, \\ 7 Quai Saint Bernard, 75252 Paris, France \\ ${ }^{3}$ Marine Biology Research Division-0202, Scripps Institution of Oceanography, La Jolla, California 92093, USA
}

\begin{abstract}
Glycogen storage in host tissue and symbiotic bacteria in the anterior trophosome of the vestimentiferan tubeworm Riftia pachyptila Jones, 1981, was investigated using transmission electron microscope and stereological methods. The relative glycogen content (RGC) of each partner was calculated from the percentage of host and bacterial cytoplasm area taken up by glycogen and from the percentage area that host and symbionts occupy within a trophosome lobule section. Our results show that host and symbionts contribute equally to the total glycogen content of the trophosome; this ratio remains similar for up to $40 \mathrm{~h}$ of hypoxia. Furthermore, there is a glycogen gradient in the lobule. In both symbiotic partners, the glycogen content increased from the lobule center toward the periphery, implying different metabolic activities of host cells and bacteria depending on their location within a trophosome lobule.
\end{abstract}

KEY WORDS: Glycogen · Riftia pachyptila $\cdot$ Symbiosis $\cdot$ Trophosome $\cdot$ Chemoautotrophic bacteria Hydrothermal vents

Resale or republication not permitted without written consent of the publisher

\section{INTRODUCTION}

The giant tubeworm Riftia pachyptila Jones, 1981 (Vestimentifera) is one of the most conspicuous members of the hydrothermal vent fauna at the East Pacific Rise (see Desbruyères \& Segonzac 1997). Its enormous tube length (up to $1.5 \mathrm{~m}$; Jones 1981) and high growth rate (Lutz et al. 1994) depend on a successful nutritional symbiosis with endosymbiotic, chemolithoautotrophic, sulfide-oxidizing bacteria (Fisher \& Childress 1986, Felbeck \& Jarchow 1998, Bright et al. 2000). The symbionts are harbored in the trophosome, a specialized organ in the trunk of $R$. pachyptila that is differentiated into lobules. Each lobule consists of 4 distinct areas: the axial blood vessel, the symbiont-containing host-cell area (termed bacteriocyte area), the sheath

*Corresponding author. E-mail: monika.bright@univie.ac.at cells, and the peripheral blood vessels (see Bright \& Sorgo in press). Most of the symbionts occur individually in specialized vacuoles termed symbiosomes; they are embedded in the peribacterial space and surrounded by the symbiosome membrane of the host (Cavanaugh et al. 1981). They are $\gamma$-Proteobacteria of a single phylotype (Nelson et al. 1984, Stahl et al. 1984, Distel et al. 1988), but display a great variation in size and shape, depending on their location within the bacteriocyte area.

The pleomorphy of the symbionts is morphologically expressed in 4 concomitant but distinguishable bacterial types (rods, and small, large, and degrading cocci) occurring in distinct zones (central, median, peripheral, degrading; Bright \& Sorgo in press), and has led to the 'gradient' and the 'cell cycle' hypotheses: (1) Biochemical gradients within each lobule result from the worm's circulatory system (with the blood flow directed from the periphery toward the center of each lobule; van der 
Land \& Nørrevang 1975, Felbeck \& Turner 1995) that supplies the symbiotic bacteria with nutrients to differing degrees (Hand 1987). (2) A coordinated cell cycle of host bacteriocytes and symbionts would lead to a permanent process of renewal through division in the center and degradation through lysis on the periphery (Bosch \& Grassé 1984a,b, Bright \& Sorgo in press).

In Riftia pachytila, glycogen reaches concentrations of up to $100 \mu \mathrm{mol}$ glycosyl units $\mathrm{g}^{-1}$ fresh wt (Arndt et al. 1998). TEM studies have shown that the trophosome tissue of $R$. pachyptila contains numerous glycogen particles at different densities (Bosch \& Grassé 1984a). These are electron-dense isodiametrical $\alpha$ particles (30 nm) usually clustered into rosettes of up to $120 \mathrm{~nm}$, and are easily distinguishable from other inclusions or organelles such as ribosomes $(20 \mathrm{~nm}$, roundish) or polysomes (chains or rings of ribosomes) (Bozzola \& Russel 1992). Glycogen serves as an important substrate for glycolysis in pro- and eukaryotes and, therefore, as an important energy source during periods of nutrient limitation. Additionally, glycogen is the only long-term energy fuel available for anaerobic metabolism (Bryant 1991).

This study determined the distribution of glycogen in different areas of the trophosome of Riftia pachyptila kept under various conditions in high-pressure flowthrough aquaria (see Arndt et al. 1998). We analyzed the glycogen density in host and bacteria separately, using quantitative morphological methods to determine the contributions of host and symbionts to the glycogen pool. The $R$. pachyptila symbiosis exhibits great tolerance toward hypoxia (Childress et al. 1984, Arndt et al. 1998). Short-term experiments under similar hypoxic conditions (already known not to affect the glycogen pool as a whole; Arndt et al. 1998), were carried out to determine whether the glycogen pools of the symbiotic partners, considered separately, were affected. An increase of glycogen in the symbionts and a decrease in the host, for example, would maintain the level of the glycogen pool for the symbiosis as a whole.

In addition, we examined differences in the glycogen storage between symbiont morphotypes and host bacteriocyte zones to determine whether the gradient hypothesis or the cell cycle hypothesis is consistent with the recorded glycogen distribution. We also recorded data on the metabolism of the host cells and bacterial morphotypes, and on metabolic interactions between the symbiotic partners.

\section{MATERIALS AND METHODS}

Collection and incubations. Twenty-five adult Riftia pachyptila were collected during the 'Hot Times 1997' expedition to the hydrothermal vent site at $9^{\circ} \mathrm{N}$ at the
East Pacific Rise. After recovery from depths of approximately $2500 \mathrm{~m}$ by the submersible 'Alvin' on Dives 3183, 3184, 3190 and 3191 in an insulated collection container at ambient pressure, the tubeworms were transferred to 210 atm in a flow-through aquarium system simulating natural conditions. To maintain them in a healthy condition, the flow-through aquaria were supplied with cold sea water $\left(15^{\circ} \mathrm{C}\right)$ containing

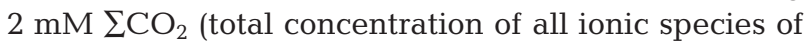
inorganic carbon), $300 \mu \mathrm{M} \sum \mathrm{H}_{2} \mathrm{~S}$ (total concentration of all ionic species of sulfide), $120 \mu \mathrm{M} \mathrm{O}_{2}$ and $400 \mu \mathrm{M}$ $\mathrm{N}_{2}$. Before starting an experiment, all worms were kept at these 'maintenance conditions' for $24 \mathrm{~h}$. A total of 19 specimens were incubated for different periods of time in hypoxic, sulfidic conditions, according to Arndt et al. (1998) (2 mM $\sum \mathrm{CO}_{2}, 300 \mu \mathrm{M} \sum \mathrm{H}_{2} \mathrm{~S}, 10$ to $16 \mu \mathrm{M}$ $\mathrm{O}_{2}$ and $400 \mu \mathrm{M} \mathrm{N}$ ): (1) 'short-term' hypoxia (11, 15, $24 \mathrm{~h} ; \mathrm{n}=9$ ), (2) 'long-term' hypoxia (40 h; $\mathrm{n}=5$ ), and (3) $40 \mathrm{~h}$ hypoxia with subsequent recovery under maintenance conditions for $17 \mathrm{~h}(\mathrm{n}=5)$. Six specimens were held in maintenance conditions for $24 \mathrm{~h}$ as controls. At the end of each experiment, the worms were sacrificed and samples were taken from their anterior trophosome tissue.

Specimen preparation. Pieces of anterior trophosome were fixed on board ship in 1.5\% acrolein, $3 \%$ glutaraldehyde and $1.5 \%$ paraformaldehyde in $0.1 \mathrm{M}$ cacodylate buffer ( $\mathrm{pH}$ 7.4) with $10 \%$ w/v sucrose added, rinsed in the same buffer, postfixed in $2 \%$ osmium tetroxyde in the same buffer, dehydrated in a series of ethanol, and embedded in Spurr's epoxy resin for transmission electron microscopy. Ultrathin sections were cut on a Reichert ultracut, placed on Formvar-coated slot-grids and stained in a Reichert stainer with uranyl acetate and lead citrate.

Stereological analysis. Trophosome lobules were examined for local distribution of glycogen, which was found in the axial peri-sinus epithelium, in the host, in the bacteria, and in the peribacterial spaces of the bacteriocyte zones and the sheath cells. Further investigations did not include (1) the axial peri-sinus epithelium (which contributes only $1.6 \%$ glycogen to the trophosome [Bright \& Sorgo in press] and in which only a few glycogen particles were visible), (2) the degrading bacteriocyte zone (in which the glycogen is already degraded and therefore not unambiguously attributable to host or bacteria) and (3) the peribacterial spaces (in which only a few glycogen particles were visible and only in those worms incubated under hypoxic conditions).

Glycogen density (GD): In this study, the term 'density' expresses the percentage of the cytoplasm area (i.e. volume fraction) taken up by glycogen in a ultrathin section. However, in comparing host and symbiont contributions in each area, similarities or differences 
in the GD reflect trends in whole cells. Five photographs each of bacterial and host tissue in each of the bacteriocyte zones and 5 images of the sheath cells of 25 worms were taken with a cooled slow-scan camera under the electron microscope LEO 912 and printed at a final magnification of $36000 \times$. As the glycogen rosettes are not uniform in color (light to dark gray) and size, they could not be identified and counted by a computer analysis program, so the stereological Chaye's dot-counting technique (Weibel \& Elias 1967) was used to calculate the GD in bacteria and host in the glycogen-containing zones: a grid of 30 dots spaced at $0.65 \mathrm{~cm}$ intervals and covering an area of $8.45 \mathrm{~cm}^{2}$ was twice laid randomly on the images.

Relative glycogen content (RGC): To calculate the glycogen content of each symbiotic partner, the GD was determined as a proportion of the percentage lobule area taken up by host and symbiont in the various ultrathin sections; i.e. the RGC for the host and symbionts in each area ( 3 bacteriocyte zones and the sheath cells) was determined, based on the GD for that area, as a percentage of the lobule area taken up by the host $(\mathrm{A} / \mathrm{h})$ or symbionts $(\mathrm{A} / \mathrm{s})(\mathrm{A} / \mathrm{h}$ and $\mathrm{A} / \mathrm{s}$ calculated by Bright \& Sorgo in press): The RGC (Table 1) was calculated with following formula: RGC $(\%)=$ $\mathrm{GD}(\%) \times \mathrm{A}(\mathrm{h} / \mathrm{s})(\%) \times 10^{-3}$.

Statistical analysis. The Tamhane post hoc multiple comparison test for unequal variances (SPSS ${ }^{\circledR} 8.00$ ) was used $(\mathrm{CI}=95 \%)$ to compare the GD of both of the multiple data sets: (1) symbiont GD (central, median, peripheral bacteriocyte zones, separately) after maintenance, short-term and long-term hypoxia, and recovery; (2) host GD (central, median, peripheral bacteriocyte zones, and sheath cells separately) after maintenance, short-term and long-term hypoxia, and recovery. Since no significant differences were found, all 25 worms were com-

Table 1. Riftia pachyptila. Trophosome lobule areas and mean percentage \pm SD of the relative glycogen content (RGC) in host and symbionts in the glycogen-containing zones ( $\mathrm{n}=25$, subsamples $=5$ )

\begin{tabular}{|lc|}
\hline Trophosome lobule & RGC \\
\hline Central bacteriocyte zone & \\
Host & $0.08 \pm 0.04$ \\
Symbionts & $0.01 \pm 0.02$ \\
Median bacteriocyte zone & \\
Host & $0.66 \pm 0.36$ \\
Symbionts & $0.47 \pm 0.46$ \\
Peripheral bacteriocyte zone & \\
Host & $0.54 \pm 0.35$ \\
Symbionts & $0.98 \pm 0.81$ \\
Sheath cells (host) & $0.29 \pm 0.25$ \\
Sum host & 1.57 \\
Sum symbionts & 1.46 \\
\hline
\end{tabular}

bined and the GD data sets for the central, median and peripheral zones (+ sheath cells for host tissue) were each compared between symbiont and host. The Kendall rank-correlation test checked for correlation of the host and bacterial GD within the 3 bacteriocyte zones. All values are means $\pm \mathrm{SD}$.

Size of bacteriocytes and bacteria in trophosome ultrathin sections. Photographs of the central, median and peripheral bacteriocyte zones were made under the transmission electron microscope LEO 902, and the negatives were scanned. The mean sizes of the bacteria in a cross-section of the central $(\mathrm{n}=500)$, median $(\mathrm{n}=$ $250)$ and peripheral $(\mathrm{n}=250)$ zones were determined using analySIS PRO ${ }^{\circledR} 3.00$. Since the cell membranes of the bacteriocytes were not continuously visible, the mean size of the bacteriocytes in each zone was based on the proportional area of bacterial and host cytoplasm in a zone (calculated by Bright \& Sorgo in press) and on the average number of bacteria in a cell.

\section{RESULTS}

Experiments. No significant differences in the GD between the 4 experiments (aerobic sulfidic maintenance, short- and long-term sulfidic hypoxia, and recovery) were detected in the host and bacterial tissues of the trophosome lobules. Therefore, all further GD and RGC calculations were made using the mean percentage of all 25 worms.

Glycogen density (GD). The different GDs in both partners of the trophosome are shown for the central and peripheral bacteriocyte zones in the transmission electron micrographs in Fig. 1. GD was not correlated between host and symbionts, and showed an inversely related trend between the symbiotic partners (Fig. 2). Bacterial GD increased from the center to the periphery, with a significant increase between the rods and the large cocci and the small and large cocci $(p<0.05)$. Host tissue GD decreased from the center toward the periphery, with a significant decrease between host tissue in the central and peripheral bacteriocyte zones, and in the the median and peripheral zones $(\mathrm{p}<0.05)$. The GD in the sheath cells was significantly lower $(p<0.01)$ then in any bacteriocyte host tissue.

Relative glycogen content (RGC). The sums of the RGCs in host and symbionts show a $1: 1$ ratio (1.57 and $1.46 \%$, respectively). Since only $2 \%$ of the symbionts are rods and the remaining $98 \%$ are cocci (Bright \& Sorgo in press), the vast majority of bacterial glycogen is of coccoid origin.

Host tissue area, bacteria and peribacterial spaces and glycogen content of a single bacteriocyte in ultrathin sections. A central rod takes up an area of $0.81 \pm$ $0.54 \mathrm{\mu m}^{2}$, a small coccus in the median zone $4.13 \pm$ 

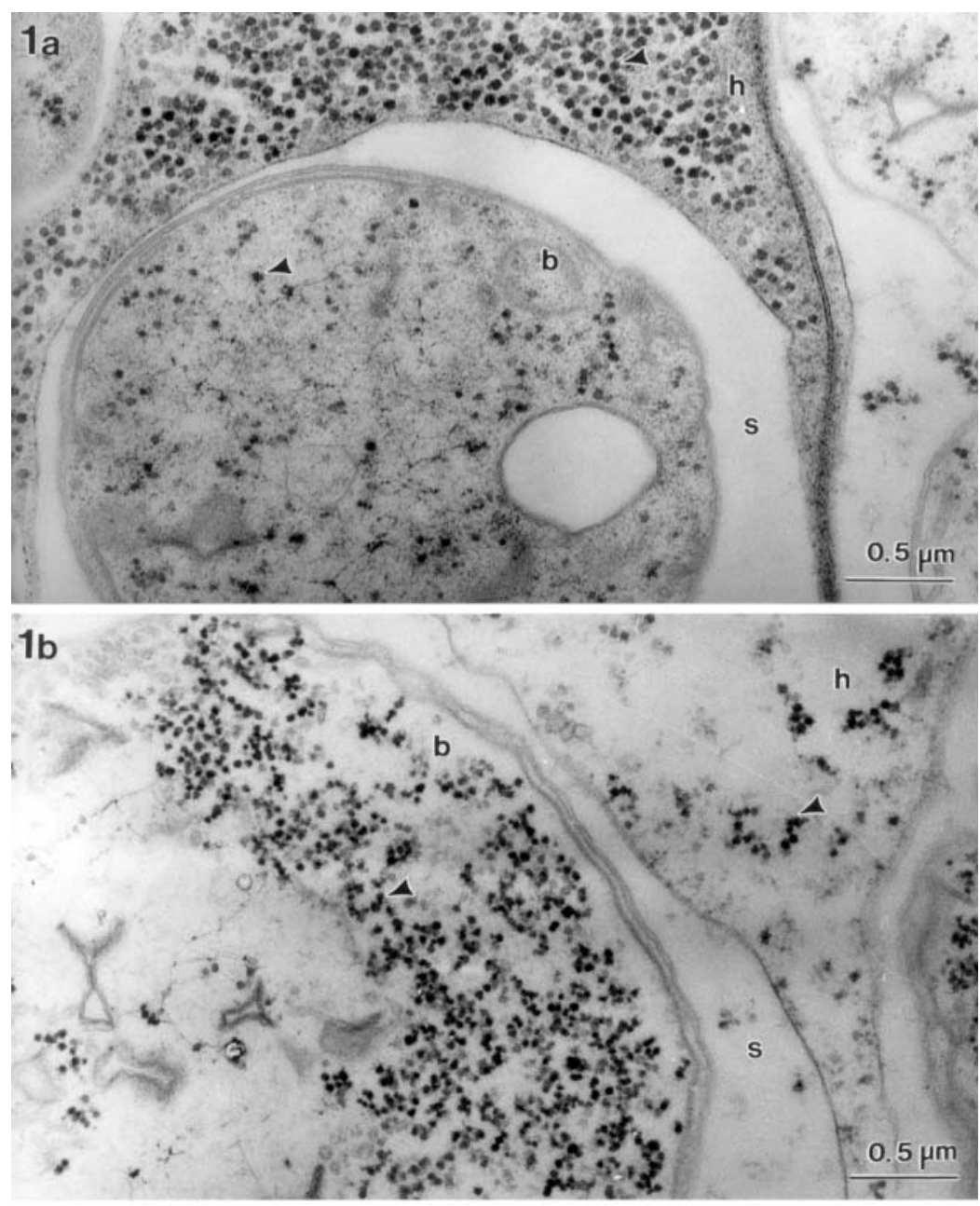

Fig. 1. Riftia pachyptila. Transmission electron micrographs of the trophosome, showing glycogen density in host and bacteria in (a) central and (b) peripheral bacteriocyte zones. h: host cell; b: bacterium; s: peribacterial space in symbiosome surrounding the bacterium; arrow heads: glycogen particles periphery, exceeding the host tissue area by a factor of 2 at the periphery (Fig. 3). Although the GD calculated for any defined area decreased in the host tissue, the glycogen content of the host tissue increased within each cell from the center to the periphery.

\section{DISCUSSION}

In Riftia pachyptila, the glycogen content of $100 \mu \mathrm{mol}$ glycosyl units $\mathrm{g}^{-1}$ fresh wt determined in the trophosome (Arndt et al. 1998) is divided equally between host and symbionts. Although the symbionts take up only $25 \%$ of the trophosome, glycogen content is distributed equally between both partners, and this ratio remains similar for up to $40 \mathrm{~h}$ of hypoxia. Thus, host and symbiont each contain about $50 \mu \mathrm{mol}$ glycosyl units $\mathrm{g}^{-1}$ fresh wt of trophosome. This amount is comparable to that in other host tissues of $R$. pachyptila, e.g. in the body wall (35 umol glycosyl units $\mathrm{g}^{-1}$ fresh wt) or the vestimentum (20 $\mu \mathrm{mol}$ glycosyl units $\mathrm{g}^{-1}$ fresh wt) (Arndt et al. 1998), to that of other chemoautotrophic symbiotic animals (Hentschel et al. 2000, Arndt pers. obs.) and to that of nonsymbiotic animals known to be adapted to long-term anoxic periods (Dales 1958, de Zwaan \& Zandee 1972, Gäde 1983, Schöttler et al. 1984, Vopel et al. 1998).

$1.9{\mu \mathrm{m}^{2}}^{2}$, and a large coccus at the periphery $17.0 \pm$ $5.6 \mathrm{\mu m}^{2}$. Thus, from the center to the periphery of a lobule, a single bacterium increases in size by 21 -fold. In a single bacteriocyte, the average number of bacteria is 36.6 in the center, 30.5 in the median zone, and 19.8 at the periphery (Bright \& Sorgo in press); the area occupied by all bacteria taken up in a single bacteriocyte is $30 \mu \mathrm{m}^{2}$ in the center, $126 \mu^{2}$ in the median zone and $341 \mu^{2}$ at the periphery. Thus, the bacterial area in any 1 bacteriocyte increases in size 11 times from the center to the periphery.

The average areas of host tissue in a single bacteriocyte (central, $38 \mu \mathrm{m}$; median, $76 \mu \mathrm{m}$; peripheral, $178 \mu \mathrm{m}$ ) and the peribacterial spaces (central, $21 \mu \mathrm{m}$; median, $45 \mu \mathrm{m}_{i}$ peripheral, $62 \mu \mathrm{m}$ ) also increase toward the periphery, but only by 5 and 3 times respectively. The bacteria take up increasingly more space within the bacteriocyte from the center toward the
The presence of glycogen in all symbionts of Riftia pachyptila indicates a surplus of carbon arising from autotrophy. The distinction of different symbiotic morphotypes of the same phylotype is based not only on size and shape modulations and on different locations within the trophosome lobules, but also on different physiological abilities. This has been proven for inorganic carbon fixation and incorporation rates (Bright et al. 2000), but is also evidenced by the increase in the amount of glycogen storage from the central rods to the large peripheral cocci.

Although the glycogen gradient is in accordance with the direction of blood flow and thus with the direction of nutrient supply, it does not support the gradient hypothesis (Hand 1987). Glycogen distribution is not correlated with incorporation rates of organic carbon, which were similarly high in the central rods and the large peripheral cocci after the 1 to 


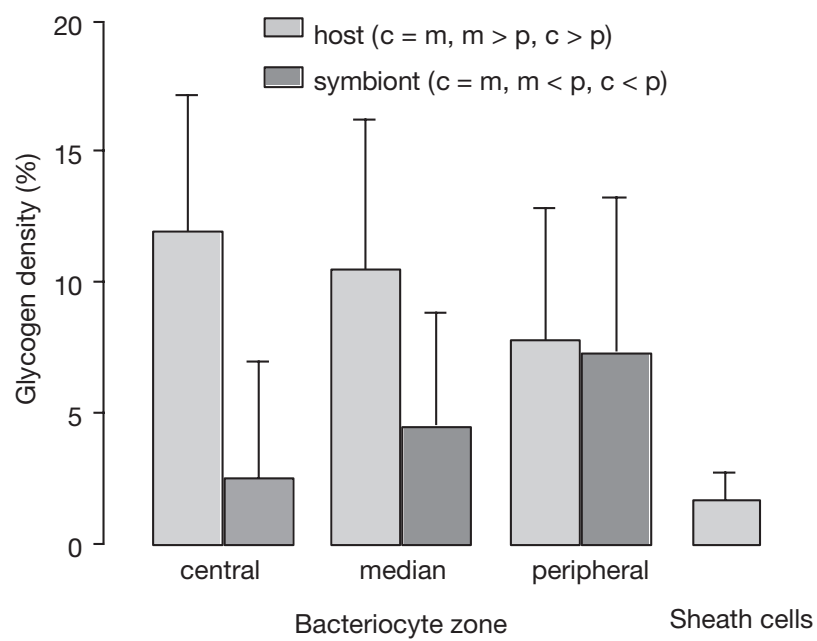

Fig. 2. Riftia pachyptila. Glycogen density (\% of cytoplasm area taken up by glycogen) in host tissue and symbionts in central (c), median (m) and peripheral (p) bacteriocyte zones and in sheath cells of the trophosome; comparisons between the glycogen density of central, median, and peripheral host and symbiont tissues were each tested with the post hoc Tamhane multiple-comparison test $(\mathrm{n}=25$, confidence level $95 \%$ ). =: not significantly different $;>,<$ : significantly greater or less, respectively

$3 \mathrm{~h}$ pulse, ${ }^{14} \mathrm{C}$-bicarbonate experiments. This organic carbon incorporation shows that there is no gradient in the compounds used in chemosynthesis (Bright et al. 2000). Even if there were some limitation to the formation of a nitrogen or phosphorus gradient (chemicals that, in free-living bacteria, are known to result in glycogen synthesis when organic carbon is available in excess; Preiss 1984, Preiss \& Romeo 1989, Lou et al. 1997), any such limitation would result in high glycogen concentrations in the center where the pool would be depleted most and low concentrations at the

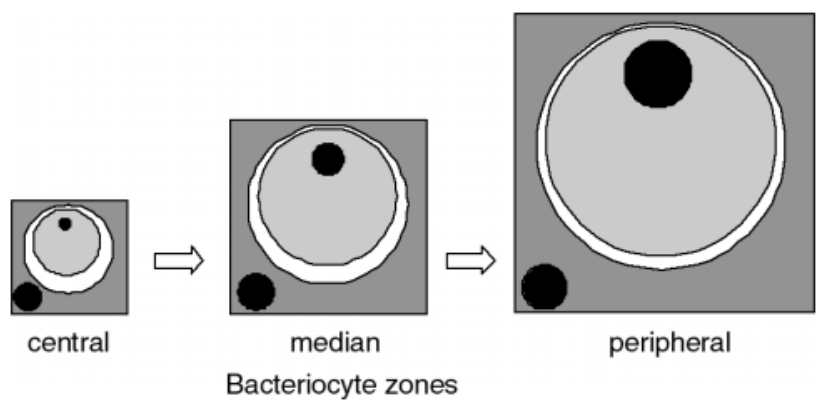

Fig. 3. Single bacteriocyte, showing areas occupied by entire host tissue (dark gray), peribacterial space (white) and symbionts (light gray) in a section, during their migration from central to peripheral bacteriocyte zones. Glycogen content (black) in both symbionts and host increases from center to periphery periphery. However, the highest values were actually found at the periphery and the lowest in the center.

Therefore, the most reasonable explanation for the rates of incorporation of organic carbon and glycogen in the lobules of the trophosome is the cell-cycle hypothesis (Bosch \& Grassé 1984a,b, Bright \& Sorgo in press): (1) The incorporation rates of organic carbon reflect the high growth rates of rods and large cocci: as an increase in biomass, growth is highest in the peripheral large cocci; as an increase in cell number, it is highest in the central rods. (2) The glycogen storage may indirectly be correlated with the division rate of the morphotypes: rods (responsible for the production of the whole bacterial population) have a high energy expenditure in division, and consequently can store little glycogen, whereas large cocci, which do not undergo division, can direct surplus organic carbon to glycogen storage.

The glycogen gradient within the host bacteriocytes is the result of positive and negative carbon flows within the trophosome; i.e. the organic carbon the bacteriocytes receive from the bacteria (positive carbon flow) and the carbon used and released by the bacteriocytes (negative carbon flow).

Positive carbon flow. (1) Carbon is released from the bacteria into the symbiosome and diffuses further through the symbiosome membrane. This mechanism as well as the amount of translocated carbon is probably controlled by the host itself, as has been shown for many algae-invertebrate symbioses (Muscatine 1967, Taylor 1971, 1973a,b, Muscatine et al. 1972, McDermott \& Blanquet 1991). However, it is not known whether the proportion of carbon released corresponds to the amount fixed. (2) After lysis of the bacteria in the degrading zone, the host cell itself degrades and all reduced compounds are released into its blood. Due to the blood flow within the lobules, the degraded compounds are once more available to the bacteriocytes.

Negative carbon flow. In this process, carbon is used and released by the bacteriocytes, and only surplus carbon can be stored in the form of glycogen. (1) Carbon is used for metabolic activities, e.g. growth and division. (2) The carbon flow to other host tissues via the circulatory system must be very high, as demonstrated by the high growth rate of the tubeworm (Lutz et al. 1994) and the glycogen stores in the other host tissues (Arndt et al. 1998).

Similar to the symbionts, the host bacteriocytes themselves are produced in the center of each lobule but cease to divide toward the periphery where they terminally differentiate (Bright \& Sorgo in press). This indicates different physiological behaviors during the different life stages of these highly specialized host cells, which is also reflected in the differences in glycogen storage. 
Acknowledgements. M.B. would like to thank J. J. Childress for his invitation to the cruise 'Hot Times 1997', the chief scientist A. Chave, and the captains and crews of the 'New Horizon', 'Atlantis' and submersible 'Alvin' for their valuable service. Thanks are due to J. Ott, H. Felbeck, U. Hentschel and 2 anonymous reviewers for critical comments on the manuscript, and C. Baranyi for helping with statistics. Financial support was provided by the Austrian Science Foundation P 13762-BIO and the Hochschuljubiläums-Stiftung of Vienna, Austria. We thank the SME-IFR 2062 CNRS and the Region Ile de France for providing TEM installation.

\section{LITERATURE CITED}

Arndt C, Schiedek D, Felbeck H (1998) Metabolic responses of the hydrothermal vent tube worm Riftia pachyptila to severe hypoxia. Mar Ecol Prog Ser 174:151-158

Bosch C, Grassé P (1984a) Cycle partiel des bactéries chimioautotrophes symbiotiques et leurs rapports avec les bactériocytes chez Riftia pachyptila Jones (Pogonophore Vestimentifère). I. Le trophosome et les bactériocytes. CR Hebd Séances Acad Sci, Paris 299:371-376

Bosch C, Grassé P (1984b) Cycle partiel des bactéries chimioautotrophes symbiotiques et leurs rapports avec les bactériocytes chez Riftia pachyptila Jones (Popgonophore Vestimentifère). II. L'évolution des bactéries symbiotiques et des bactériocytes. CR Hebd Séances Acad Sci, Paris 299:413-419

Bozzola JJ, Russel LD (1992) Electron microscopy. Principles and techniques for biologists. Jones \& Bartlett, Boston, MA

Bright M, Sorgo A (2002) Ultrastructural reinvestigation of the trophosome in adult Riftia pachyptile (Vestimentifera). Invertebr Biol (in press)

Bright M, Keckeis H, Fisher CR (2000) An autoradiographic examination of carbon fixation, transfer, and utilization in the Riftia pachyptila symbiosis. Mar Biol 136:621-632

Bryant C (1991) Metazoan life without oxygen. Chapman \& Hall, London

Cavanaugh CM, Gardiner SL, Jones ML, Jannasch HW, Waterbury JB (1981) Prokaryotic cells in the hydrothermal vent tube worm Riftia pachyptila Jones: possible chemoautotrophic symbionts. Science 213:340-342

Childress JJ, Arp AJ, Fisher CR Jr (1984) Metabolic and blood characteristics of the hydrothermal vent tube-worm Riftia pachyptila. Mar Biol 83:109-124

Dales RP (1958) Survival of anaerobic periods by two intertidal polychaetes, Arenicola marina L. and Owenia fusiformis Delle Chiaje. J Mar Biol Assoc UK 37:521-529

Desbruyères D, Segonzac M (1997) Handbook of deep-sea hydrothermal vent fauna. Éditions IFREMER, Brest

de Zwaan A, Zandee DI (1972) Body distribution and seasonal changes in the glycogen content of the common sea mussel Mytilus edulis. Comp Biochem Physiol 43A:53-58

Distel DL, Lane DJ, Olsen GJ, Giovannoni SJ, Pace B, Pace NR, Stahl DA, Felbeck H (1988) Sulfur-oxidizing bacterial endosymbionts: analysis of phylogeny and specificity by 16S rRNA sequences. J Bacteriol 170:2506-2510

Felbeck H, Jarchow J (1998) Carbon release from purified chemoautotrophic bacterial symbionts of the hydrothermal vent tubeworm Riftia pachyptila. Physiol Zool 71: 294-302

Felbeck H, Turner PJ (1995) $\mathrm{CO}_{2}$ transport in catheterized hydrothermal vent tubeworms, Riftia pachyptila (Vestimentifera). J Exp Zool 272:95-102

Editorial responsibility: Otto Kinne (Editor), Oldendorf/Luhe, Germany
Fisher CR, Childress JJ (1986) Translocation of fixed carbon from symbiotic bacteria to host tissues in the gutless bivalve Solemya reidi. Mar Biol 93:59-68

Gäde G (1983) Energy metabolism of arthropods and mollusks during environmental and functional anaerobiosis. J Exp Zool 228:415-429

Hand SC (1987) Trophosome ultrastructure and the characterization of isolated bactericytes from invertebrate-sulfur bacteria symbioses. Biol Bull 173:260-276

Hentschel W, Millikan DS, Arndt C, Cary SC, Felbeck H (2000) Phenotypic variations in the gills of the symbiontcontaining bivalve Lucinoma aequizonata. Mar Biol 136: $633-644$

Jones ML (1981) Riftia pachyptila Jones: observations on the vestimentiferan worm from the Galápagos Rift. Science 213:333-336

Lou J, Dawson KA, Strobel HJ (1997) Glycogen formation by the ruminal bacterium Prevotella ruminicola. Appl Environ Microbiol 63:1483-1488

Lutz RA, Shank TM, Fornari DJ, Haymon RM, Lilley MD, von Damm KL, Desbruyères D (1994) Rapid growth at deepsea vents. Nature 371:663-664

McDermott AM, Blanquet RS (1991) Glucose and glycerol uptake by isolated zooxanthellae from Cassiopeia xamachana: transport mechanisms and regulation by host homogenate fractions. Mar Biol 108:129-136

Muscatine L (1967) Glycerol excretion by symbiotic algae from corals and Tridacna and its control by the host. Science 156:516-519

Muscatine L, Pool RR, Cernichiari E (1972) Some factors influencing selective release of soluble organic material by zooxanthellae from reef corals. Mar Biol 13:298-308

Nelson DC, Waterbury JB, Jannasch HW (1984) DNA base composition and genome size of the prokaryotic symbiont in Riftia pachyptila (Pogonophora). FEMS Microbiol Lett 24:267-271

Preiss J (1984) Bacterial glycogen synthesis and its regulation. Annu Rev Microbiol 38:419-458

Preiss J, Romeo T (1989) Physiology, biochemistry and genetics of bacterial glycogen synthesis. Adv Microb Physiol 30: $183-238$

Schöttler U, Wienhausen G, Westermann J (1984) Anaerobic metabolism in the lugworm Arenicola marina L.: the transition from aerobic to anaerobic metabolism. Comp Biochem Physiol 79B:93-103

Stahl DA, Lane DJ, Olsen GJ, Pace NR (1984) Analysis of hydrothermal vent-associated symbionts by ribosomal RNA sequences. Science 224:409-411

Taylor DL (1971) Patterns of carbon translocation in algalinvertebrate symbiosis. In: Nisizawak K (ed) Proc 7th Int Seaweed Symp, Tokyo. University of Tokyo Press, Tokyo, p 590-597

Taylor DL (1973a) The cellular interactions of algal-invertebrate symbiosis. Adv Mar Biol 11:1-56

Taylor DL (1973b) Symbiotic pathways of carbon in coral reef ecosystems. Helgol Wiss Meeresunters 24:276-283

van der Land J, Nørrevang A (1975) The systematic position of Lamellibrachia (Annelida, Vestimentifera). Z Zool Syst Evolutionsforsch (Sonderhft) 1:86-101

Vopel K, Dehmlow J, Johansson M, Arlt G (1998) Effects of anoxia and sulphide on populations of Cletocamptus confluens (Copepoda, Harpacticoida). Mar Ecol Prog Ser 175: 121-128

Weibel ER, Elias H (1967) Quantitative methods in morphology. Springer-Verlag, Berlin

Submitted: September 12, 2000; Accepted: June 7, 2001

Proofs received from author(s): March 26, 2002 